\title{
Front Matter: Volume 10478
}

, "Front Matter: Volume 10478," Proc. SPIE 10478, Molecular-Guided Surgery: Molecules, Devices, and Applications IV, 1047801 (25 April 2018); doi: $10.1117 / 12.2315735$

SPIE. Event: SPIE BiOS, 2018, San Francisco, California, United States 


\title{
Molecular-Guided Surgery: Molecules, Devices, and Applications IV
}

\author{
Brian W. Pogue \\ Sylvain Gioux \\ Editors
}

\section{7-29 January 2018}

San Francisco, California, United States

Sponsored by

SPIE

Cosponsored by

Intuitive Surgical (United States)

Invuity, Inc. (United States)

LI-COR (United States)

Modulated Imaging (United States)

Mauna Kea Technologies (France)

PerkinElmer (United States)

SurgiMab (France)

SurgVision (Netherlands)

Published by

SPIE 
The papers in this volume were part of the technical conference cited on the cover and title page. Papers were selected and subject to review by the editors and conference program committee. Some conference presentations may not be available for publication. Additional papers and presentation recordings may be available online in the SPIE Digital Library at SPIEDigitalLibrary.org.

The papers reflect the work and thoughts of the authors and are published herein as submitted. The publisher is not responsible for the validity of the information or for any outcomes resulting from reliance thereon.

Please use the following format to cite material from these proceedings:

Author(s), "Title of Paper," in Molecular-Guided Surgery: Molecules, Devices, and Applications IV, edited by Brian W. Pogue, Sylvain Gioux, Proceedings of SPIE Vol. 10478 (SPIE, Bellingham, WA, 2018) Seven-digit Article CID Number.

ISSN: 1605-7422

ISSN: 2410-9045 (electronic)

ISBN: 9781510614413

ISBN: 9781510614420 (electronic)

Published by

SPIE

P.O. Box 10, Bellingham, Washington $98227-0010$ USA

Telephone +1 3606763290 (Pacific Time) · Fax +1 3606471445

SPIE.org

Copyright (C) 2018, Society of Photo-Optical Instrumentation Engineers.

Copying of material in this book for internal or personal use, or for the internal or personal use of specific clients, beyond the fair use provisions granted by the U.S. Copyright Law is authorized by SPIE subject to payment of copying fees. The Transactional Reporting Service base fee for this volume is $\$ 18.00$ per article (or portion thereof), which should be paid directly to the Copyright Clearance Center (CCC), 222 Rosewood Drive, Danvers, MA 01923. Payment may also be made electronically through CCC Online at copyright.com. Other copying for republication, resale, advertising or promotion, or any form of systematic or multiple reproduction of any material in this book is prohibited except with permission in writing from the publisher. The CCC fee code is 1605$7422 / 18 / \$ 18.00$.

Printed in the United States of America.

Publication of record for individual papers is online in the SPIE Digital Library.

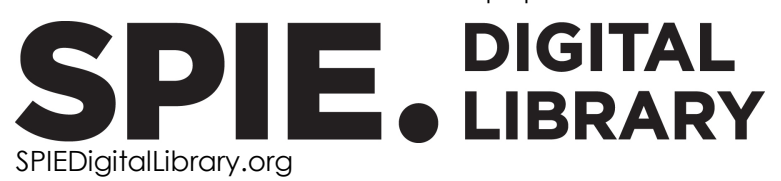

Paper Numbering: Proceedings of SPIE follow an e-First publication model. A unique citation identifier (CID) number is assigned to each article at the time of publication. Utilization of CIDs allows articles to be fully citable as soon as they are published online, and connects the same identifier to all online and print versions of the publication. SPIE uses a seven-digit CID article numbering system structured as follows:

- The first five digits correspond to the SPIE volume number.

- The last two digits indicate publication order within the volume using a Base 36 numbering system employing both numerals and letters. These two-number sets start with 00, 01, 02, 03, 04, 05, 06, 07, 08, 09, OA, OB ... OZ, followed by 10-1Z, 20-2Z, etc. The CID Number appears on each page of the manuscript. 


\title{
Contents
}

\author{
$\checkmark$ Authors \\ vii Conference Committee
}

\section{ADVANCED DETECTION METHODS I}

1047804 Optimizing fluorescently tethered Hsp90 inhibitor dose for maximal specific uptake by breast tumors [10478-3]

1047806 Raman spectroscopic analysis for gastric and colorectal cancer in surgical treatment toward molecular-guided surgery [10478-5]

\section{ADVANCED DETECTION METHODS II}

1047809 Optimization of the incident wavelength in Mueller matrix imaging of cervical collagen [10478-8]

\section{CONTRAST AGENTS}

10478 Ol Improved identification of cranial nerves using paired-agent imaging: topical staining protocol optimization through experimentation and simulation [10478-19]

\section{CLINICAL TRANSLATION AND CLINICAL APPLICATIONS I}

$10478 \mathrm{ON}$ Thick tissue diffusion model with binding to optimize topical staining in fluorescence breast cancer margin imaging [10478-24]

1047800 Fluorescent humanized anti-CEA antibody specifically labels metastatic pancreatic cancer in a patient-derived orthotopic xenograft (PDOX) mouse model [10478-25]

JOINT SESSION WITH CONFERENCES 10476 AND 10478: ISOTOPE OPTICAL IMAGING AND CANCER

$1047811 \quad$ Flexible scintillator autoradiography for tumor margin inspection using ${ }^{18 F-F D G ~[10478-38] ~}$ 
JOINT SESSION WITH CONFERENCES 10476 AND 10478: RADIATION THERAPY OPTICAL IMAGING AND SENSING

1047812 Single photon detection imaging of Cherenkov light emitted during radiation therapy [10478-39]

1047815 Characterization of the proton irradiation induced luminescence of materials and application in radiation oncology dosimetry [10478-42]

1047816 Cherenkov imaging for Total Skin Electron Therapy (TSET) [10478-47]

POSTER SESSION

1047817 NADPH as a potential intrinsic probe for fumour margin estimation [10478-43] 


\section{Authors}

Numbers in the index correspond to the last two digits of the seven-digit citation identifier (CID) article numbering system used in Proceedings of SPIE. The first five digits reflect the volume number. Base 36 numbering is employed for the last two digits and indicates the order of articles within the volume. Numbers start with 00, 01, 02, 03, 04, 05, 06, 07, 08, 09, OA, OB...0Z, followed by 10-12, 20-2Z, etc.

Adamson, Philip M., 12

Andreozzi, Jacqueline M., 12, 16

Arridge, S. R., 11

Birch, David J. S., 17

Bouvet, Michael, 00

Bruza, Petr, 16

Byrne, Richard W., Ol

Chue-Sang, Joseph, 09

Clary, Bryan, 00

Crouch, Brian T., 04

Darafsheh, Arash, 15

DeLong, Jonathan C., 00

Dong, Lei, 16

Duer, Joy, 04

Finlay, Jarod C., 15

Gallagher, Jennifer, 04

Gladstone, David J., 12

Grootendorst, M., 11

Hall, Allison, 04

Haystead, Timothy A. J., 04

Hoffman, Robert M., 00

Hughes, Philip, 04

Hupp, Ted R., 17

Kang, Soyoung, ON

Kassaee, Alireza, 15

Koga, Shigehiro, 06

LaRochelle, Ethan, 12

Liv, Jonathan T. C., ON

Lwin, Thinzar M., 00

Macholl, S., 11

Maity, Amit, 16

Mertzanidou, T., 11

Miao, Tianshun, 16

Miyake, Kentaro, 00

Murakami, Takashi, 00

Navarro-Comes, Eric, ON

Oshima, Yusuke, 06

Petroccia, Heather, 16

Plastaras, John P., 16

Pogue, Brian W., 12, 16

Ramanujam, Nirmala, 04

Ramella-Roman, Jessica C., 09

Shivley, John E., 00

Soo, Mary Scott, 04

Staneviciute, Austeja, 0

Stewart, Hazel L., 17

Stoyanov, D., 11

Tichaver, Kenneth M., OI, ON

Torres, Veronica C., 01
Tuch, D. S., 11

Vyas, K. N., 11

Wang, Roujia, 04

Wang, Yu, ON

Watanabe, Yuji, 06

Wilson, Todd, 01

Xie, Yunhe, 16

$X U$, Xiaochun, ON

Yazaki, Paul J., 00

Zhang, Rongxiao, 15

Zhu, Timothy C., 16

Zhu, Yihua, 16 
Proc. of SPIE Vol. 10478 1047801-6

Downloaded From: https://www.spiedigitallibrary.org/conference-proceedings-of-spie on 25 Apr 2023 Terms of Use: https://www.spiedigitallibrary.org/terms-of-use 


\title{
Conference Committee
}

\author{
Symposium Chairs
}

James G. Fujimoto, Massachusetts Institute of Technology

(United States)

R. Rox Anderson, Wellman Center for Photomedicine, Massachusetts General Hospital (United States) and Harvard Medical School (United States)

Program Track Chair

Brian Jet-Fei Wong, Beckman Laser Institute and Medical Clinic (United States)

Conference Chairs

Brian W. Pogue, Thayer School of Engineering at Dartmouth (United States)

Sylvain Gioux, Université de Strasbourg (France)

Conference Program Committee

Michael Bouvet, University of California, San Diego (United States)

David J. Cuccia, Modulated Imaging, Inc. (United States)

Michele Diana, The Institute of Image-Guided Surgery of Strasbourg (France)

Fernando Dip, Consultant (United States)

Summer L. Gibbs, Oregon Health \& Science University (United States)

Hisataka Kobayashi, National Cancer Institute (United States)

Frédéric Leblond, Ecole Polytechnique de Montréal (Canada)

Jonathan T.C. Liu, University of Washington (United States)

Vasilis Ntziachristos, Helmholtz Zentrum München GmbH (Germany)

Keith D. Paulsen, Thayer School of Engineering at Dartmouth (United States)

Eben L. Rosenthal, Stanford Health Care (United States)

Jonathan M. Sorger, Intuitive Surgical, Inc. (United States)

Tomasz S. Tkaczyk, Rice University (United States)

Kenneth M. Tichaver, Illinois Institute of Technology (United States)

Alex Vahrmeijer, Leiden University Medical Center (Netherlands)

Thomas D. Wang, University of Michigan (United States)

Brian C. Wilson, Ontario Cancer Institute (Canada)

Siavash Yazdanfar, GE Global Research (United States) 


\section{Session Chairs}

1 Advanced Detection Methods I

Frédéric Leblond, Ecole Polytechnique de Montréal (Canada)

Nils Petitdidier, CEA-LETI (France)

2 Advanced Detection Methods II

Nicholas J. Durr, Johns Hopkins University (United States)

Jonathan T.C. Liu, University of Washington (United States)

3 Imaging Systems

Daniel S. Elson, Imperial College London (United Kingdom)

4 Contrast Agents

Kenneth M. Tichaver, Illinois Institute of Technology (United States)

Joseph P. Angelo Jr., National Institute of Standards and Technology (United States)

5 Clinical Translation and Clinical Applications I

Hak Soo Choi, Massachusetts General Hospital (United States)

Jakob Unger, University of California, Davis (United States)

6 Clinical Translation and Clinical Applications II

Summer L. Gibbs, Oregon Health \& Science University (United States)

Conor L. Evans, Wellman Center for Photomedicine (United States)

$7 \quad$ Clinical Translation and Clinical Applications III

Sylvain Gioux, Université de Strasbourg (France)

Jonathan Sorger, Intuitive Surgical, Inc. (United States)

8 Joint Session with Conferences 10476 and 10478: Isotope Optical

Imaging and Cancer

Brian W. Pogue, Thayer School of Engineering at Dartmouth (United States)

9 Joint Session with Conferences 10476 and 10478: Radiation Therapy Optical Imaging and Sensing

Brian W. Pogue, Thayer School of Engineering at Dartmouth (United States) 